\title{
The Historical Development of Cartography in Albania
}

\author{
Fadil SHEHU1', Ferat SHALA² \\ 1 H.P. "Iber Lepenc", Sheshi "Bill Clinton" br.13, 10000 Priština, Kosovo \\ fadil.shehu01@gmail.com \\ 2 University of Priština, Faculty of Mechanical Engineering, Lagjja Bregu i Diellit p.n., 10000 Priština, Kosovo \\ ferat.shala@uni-pr.edu (author for correspondence)
}

Abstract. The aim of this expert paper is to show development in the area of cartography in chronological order from the time when Albania first appeared on maps by well-known Venetian cartographers (with toponyms in Albanian). An overview of various topographic maps and maritime charts is presented, along with the relevant local and international institutions whose main activities were cartography and geoinformation during different periods. An expert opinion is expressed on the current state of cartographic and geoinformation data as a scientific discipline, with a special emphasis on alignment with international standards.

Keywords: Albania, cartography, map, GIS, cartographic institute, mapping projection, topographic map, maritime chart, topographic institue, ALUIZNI, INSPIRE, National Geoportal, ASIG

\section{The geography of Albania}

Albania is a southeast European state situated in the western part of the Balkan peninsula between $39^{\circ} 39^{\prime} \mathrm{N}$ and $42^{\circ} 41^{\prime} \mathrm{N}$ and $19^{\circ} 15^{\prime} \mathrm{E}$ and $21^{\circ} 7^{\prime} \mathrm{E}$. The length of the border of the Republic of Albania is $1,094 \mathrm{~km}$, of which $657 \mathrm{~km}$ are on land, $316 \mathrm{~km}$ at sea, $48 \mathrm{~km}$ along rivers, and $73 \mathrm{~km}$ on lakes. In the west, Albania adjoins the Adriatic Sea, and in the southwest, the Ionian Sea. The country is about $72 \mathrm{~km}$ from Italy if one considers the route through the Channel of Otranto which links the Adriatic and Ionian Seas. The median height above sea level is $708 \mathrm{~m}$, which is twice as high as the average for Europe as a whole. Albania belongs to the subtropical zone of the humid northern hemisphere, and overall belongs to the Mediterranean climate zone. The country has a parliamentary democracy and its economy is in the transition phase. The official language is Albanian (a specific branch of the wider group of Indo-European languages). The capital is Tirana, which is also the

largest city in Albania. Today, Tirana is the political, economic and cultural centre of the country and has a population of over 700,000 . In recent years, a great deal has been done to achieve progress and the capital has developed significantly. Modern infrastructure has given the city a true metropolitan appearance, spirit and character (Google 2020b). The National History Museum and Albanian national educational system are the most important bearers of formal interpretation of the country's history. They play a significant role in protecting the nation's identity and in conveying its image to visitors and the outside world. Butrint National Park is a natural resource which has gained enviable recognition and was inscribed in the UNESCO World Heritage List in 1992 (Wikipedia 2012b).

\section{Albania on Venetian Maps}

Maps of the Adriatic which included Albania were mostly produced by famous Western European

KiG No. 34, Vol. 19, 2020 https://doi.org/10.32909/kg.19.34.1 - ـ 


\title{
Povijesni razvoj kartografije u Albaniji
}

\author{
Fadil SHEHU1, Ferat SHALA² \\ 1 H.P. "Iber Lepenc", Sheshi "Bill Clinton" br.13, 10000 Priština, Kosovo \\ fadil.shehu01@gmail.com \\ 2 Sveučilište u Prištini, Strojarski fakultet, Lagjja Bregu i Diellit p.n., 10000 Priština, Kosovo \\ ferat.shala@uni-pr.edu (autor za korespondenciju)
}

Članak je na engleski jezik prevela J. Berković. The paper was translated into English by J. Berković.

Sažetak. Svrha je ovoga stručnog rada kronološkim redoslijedom prikazati razvoj na području kartografije od vremena kada je Albanija prvi put pronađena na kartama poznatih venecijanskih kartografa s toponimima na albanskom jeziku. Izvršen je pregled različitih topografskih i pomorskih karata, kao i relevantnih lokalnih i međunarodnih institucija u različitim vremenskim razdobljima čija je glavna djelatnost bila područje kartografije i geoinformacije. Izneseno je stručno mišljenje o trenutnom stanju kartografskih i geoinformacijskih podataka kao znanstvene discipline s posebnim naglaskom na usklađivanje tih podataka s međunarodnim standardima.

KIjučne riječi: Albanija, kartografija, karta, GIS, kartografski institut, kartografska projekcija, topografske karte, pomorske karte, topografski institut, ALUIZNI, INSPIRE, Nacionalni geoportal, ASIG

\section{Geografija Albanije}

Albanija je jugozapadna europska država smještena na zapadu Balkanskog poluotoka između geografskih koordinata: $39^{\circ} 39^{\prime}$ i $42^{\circ} 41^{\prime}$ širine te $19^{\circ} 15^{\prime}$ i $21^{\circ} 7^{\prime}$ dužine. Duljina granične crte Republike Albanije iznosi $1094 \mathrm{~km}$, od čega $657 \mathrm{~km}$ čini kopnenu graničnu crtu, 316 km morsku, 48 km riječnu i $73 \mathrm{~km}$ jezersku graničnu crtu. Sa zapadne strane dodiruje ju Jadransko more, a na jugozapadu Jonsko more. Udaljena je oko $72 \mathrm{~km}$ od Italije, računajući put preko Otrantskog kanala koji veže Jadransko i Jonsko more. Srednja nadmorska visina iznosi $708 \mathrm{~m}$, što znači da je dva puta veća nego ona prosječna za čitavu Europu. Albanija pripada subtropskoj zoni vlažne sjeverne hemisfere te sveukupno gledajući pripada sredozemnoj klimatskoj zoni. Albanija je parlamentarna demokratska zemlja s gospodarstvom koje se nalazi u fazi tranzicije. Službeni je jezik albanski (jedna specifična grana šire i mnogoznačne skupine indoeuropskih jezika). Glavni grad Albanije je Tirana, prijestolnica, a ujedno i najveći grad Albanije. Danas je Tirana politički, gospodarski i kulturni centar zemlje s više od 700000 stanovnika. Posljednjih se godina puno učinilo po pitanju njezinog unaprjeđenja - glavni grad se vidno razvio. Moderna infrastruktura gradu je dala pravi metropolitski izgled, duh i karakter (Google 2020b). Nacionalni povijesni muzeji, kao i albanski nacionalni obrazovni sustav, jedni su od najvažnijih nositelja formalne interpretacije povijesti jedne zemlje. Oni igraju važnu ulogu u zaštiti identiteta nacije, kao i u prenošenju vlastite slike posjetiteljima i vanjskom svijetu. Nacionalno je butrintsko prirodno blago dobilo zavidno priznanje tako što je 1992. godine registrirano na listi Svjetske baštine UNESCA od strane Svjetske komisije zadužene za ta pitanja (Wikipedia 2012b). 


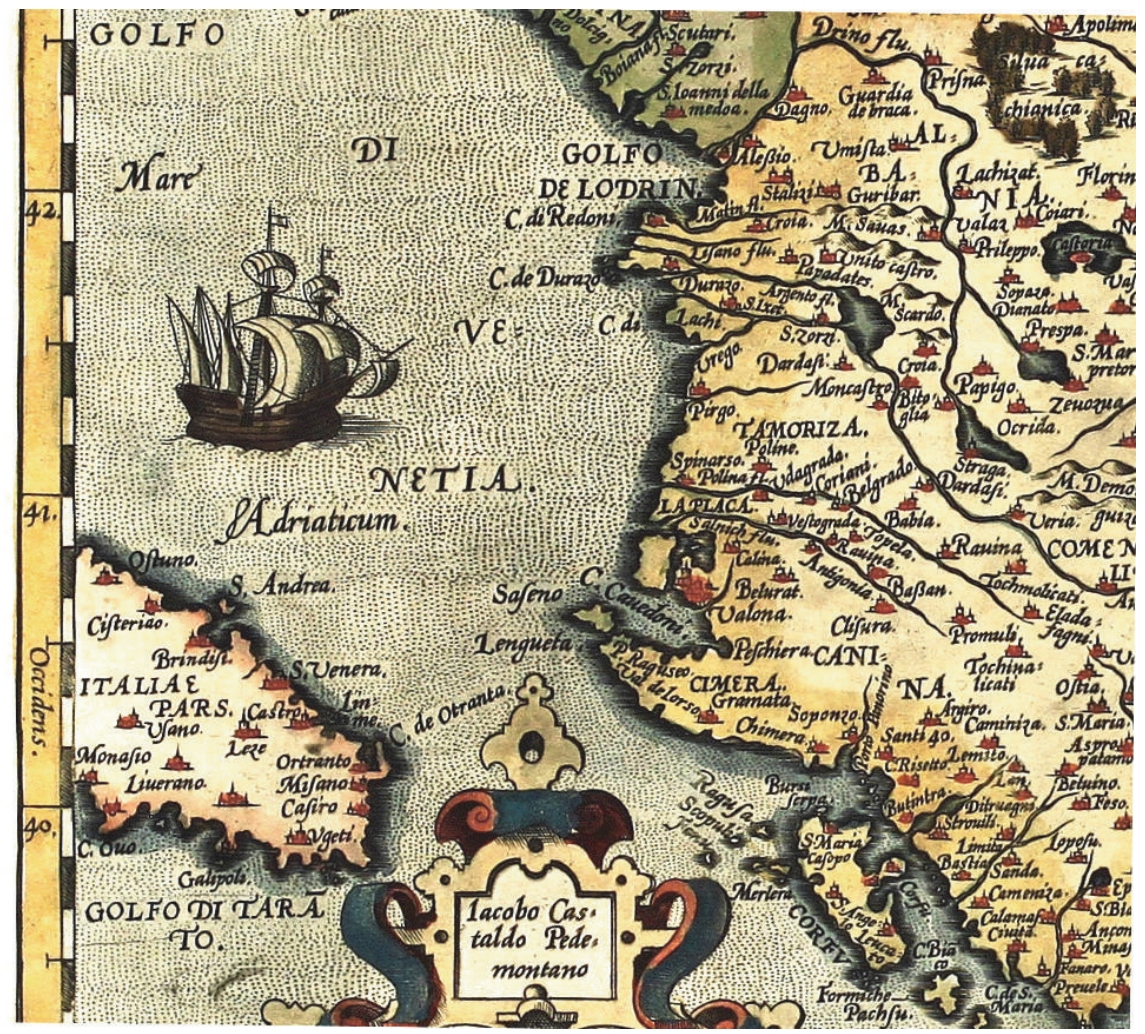

Fig. 1 A fragment of the map of Greece (Graeciae universae secundum hodiernum situm neoterical descriptio) by Giacomo Gastaldi from 1570 on which Albania appears (https://www.vintage-maps.com/en/antique-maps/europe/greece/orteliusgreece-peloponnese-aegean-crete-asia-minor::1282).

Slika 1. Isječak karte Grčke (Graeciae universae secundum hodiernum situm neoterical descriptio) Giacoma Gastaldija iz 1570. na kojoj je označena i Albanija (https://www.vintage-maps.com/en/antique-maps/europe/greece/ortelius-greece-peloponnese-aegean-crete-asia-minor::1282).

cartographers. One, produced by the well-known cartographer Pietro Vesconte of Genoa in 1320, was the first maritime chart of the Adriatic Sea. Today it is housed in the Marciana Library in Venice. The next example of a maritime chart including Albania is dated 1435 and was produced by the then wellknown and highly acknowledged cartographer Battista Beccario of Genoa. It is also housed in the Marciana Library in Venice. The most famous cartographer in 16th-century Italy, Giacomo (Jacopo, Iacopo) Gastaldi (1520-1565) produced a map of Greece showing Albania, and was significant because for the first time, toponyms in Albanian appeared (Figure 1) (Google 2012a).

The Genoese priest and cartographer Bartolomeo Pareto produced a famous nautical chart on which he marked Albania. He signed it in Genoa in 1455, and it is kept in the National Library in Rome. A copy of the map was taken to Albania for the first time in 2017 by the famous Albanian cartographer Artan Shkreli, and is housed in the National Museum of Albania (Figure 2) (Shkreli 2017).

\section{Cartography of Albania Before and During the First World War}

The entire development of cartography in Albania from 1913 on was implemented by the Viennese Military Geographic Institute, which established two provisional cartography centres in Tirana and Skadar at that time. Then, maps in the scale 1:75,000 covered the entire territory of Albania. An existing map in the scale 1:300,000 published by the Viennese Military Geographic Institute in 1876 was used as the cartographic base. It should be mentioned that the projection mapping Bessel ellipsoid had its starting-point in the coastal town of Skadar $\mathrm{dL}=17^{\circ} 39^{\prime} 46.5^{\prime \prime}$, and the density of trigonometric points was as much as $40 \mathrm{~km}$ between points. In 1925, the Albanian Ministry of Education requested the Viennese Military Geographic Institute to republish its map of Albania in the scale of 1:75,000 in the Gauss-Krüger projection. The maps published by the Viennese Military Geographic Institute served the Republic of Albania as a cartographic basis from KiG No. 34, Vol. 19, 2020, https://doi.org/10.32909/kg.19.34.1 - 


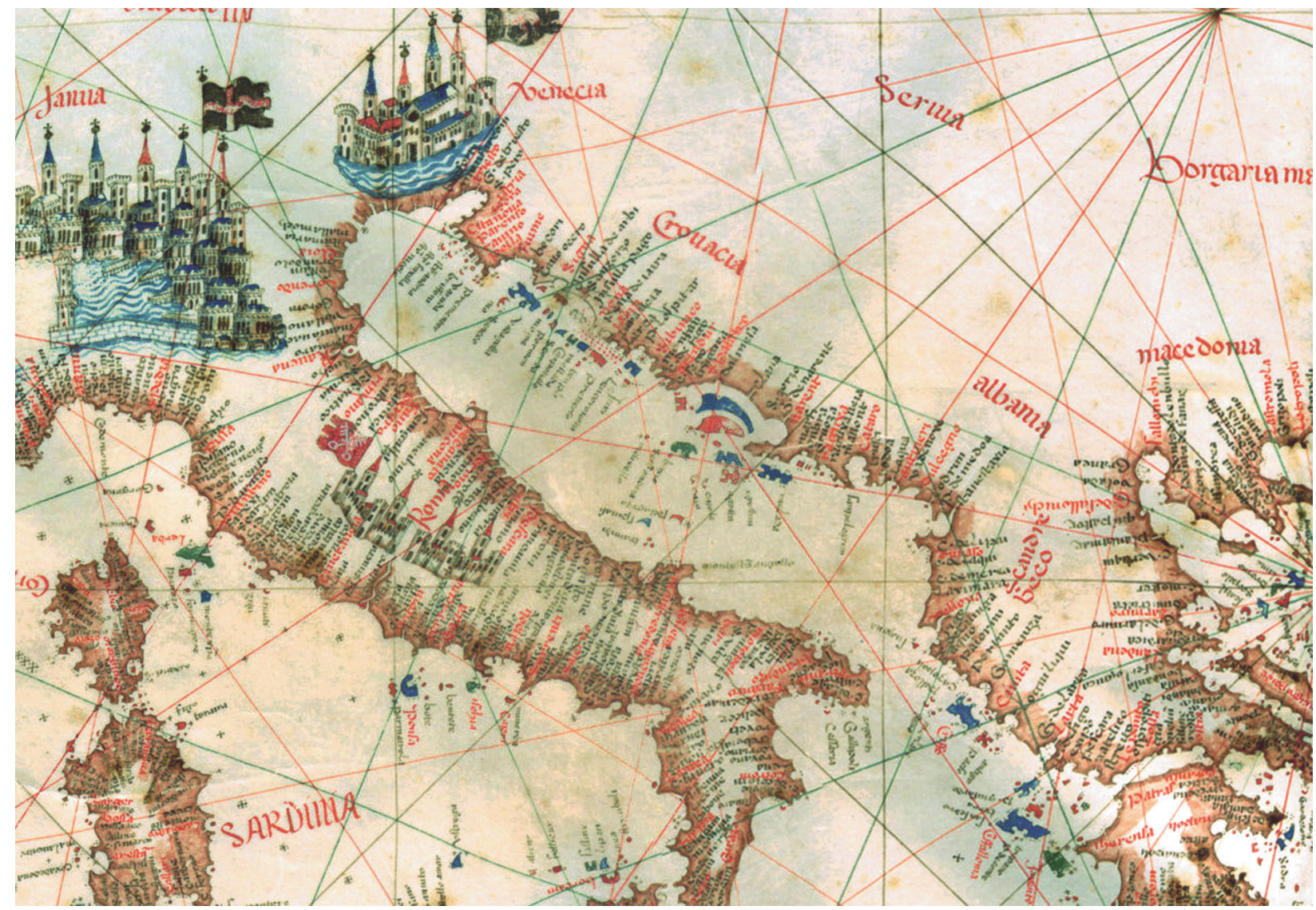

Slika 2. Isječak pomorske karte, jedinog sačuvanog djela Bartolomea Pareta, svećenika i kartografa iz Genove, 15. stoljeće (https://commons.wikimedia.org/wiki/File:1455_Nautical_Chart_by_Bartolomeo_Pareto.jpg).

Fig. 2 A fragment of a nautical chart on which Albania appears, the only surviving work of Bartolomeo Paret, a priest and cartographer from Genoa, 15th century (https://commons.wikimedia.org/wiki/File:1455_Nautical_Chart_by_Bartolomeo_Pareto.jpg).

\section{Albanija na kartama Venecije}

Karte Jadranskoga mora, na kojima je ucrtana i Albanija, uglavnom su izrađivali poznati kartografi zapadne Europe. Kao prvu pomorsku kartu Jadranskog mora vrijedi spomenuti onu izrađenu od strane tadašnjeg poznatog kartografa Pietra Vescontea iz Genove, a nastala je 1320. godine. Danas se čuva u knjižnici Marciana u Veneciji. Nakon nje nailazimo na primjer pomorske karte Jadranskoga mora u koju je ucrtana i Albanija, a koju je izradio tadašnji poznati i priznati kartograf Battista Beccario iz Genove. Datira iz 1435. godine i također se čuva u knjižnici Marciana u Veneciji. Najpoznatiji kartograf XVI. stoljeća u Italiji bio je Giacomo (Jacopo, Iacopo) Gastaldi (1520-1565). Izradio je kartu Grčke na kojoj je prikazana i Albanija, a značajna je po tome što se na njoj prvi put susrećemo s toponimima na albanskom jeziku (slika 1) (Google 2012a).

Đenovski svećenik i kartograf Bartolomeo Pareto izradio je čuvenu nautičku kartu na kojoj je zabilježena i Albanija. Potpisao ju je u Genovi 1455. godine, a čuva se u Nacionalnoj knjižnici u Rimu. Kopiju te karte prvi je put u Albaniju 2017. godine donio poznati albanski kartograf Artan Shkreli, a čuva se u Nacionalnom muzeju Albanije (slika2) (Shkreli 2017).

\section{Kartografija Albanije prije i tijekom Prvoga svjetskog rata}

Sav razvoj na području kartografije u Albaniji u razdoblju od 1913. godine proveo je Bečki vojnogeografski institut koji je u to doba osnovao dva privremena kartografska centra u Albaniji i to u gradovima Tirani i Skadru. Karte u mjerilu 1:75 000 tada su pokrivale cjelokupni teritorij Albanije. Postojeća karta u mjerilu 1:300 000, izdanje Bečkog vojnogeografskog instituta iz 1876. godine, korištena je kao kartografska osnova. Vrijedi napomenuti da je kartografska projekcija Basselovog elipsoida imala polazište u obalnom gradu Skadru s geografskom dužinom $\mathrm{dL}=$ $17^{\circ} 39^{\prime} 46,5^{\prime \prime}$, gdje je gustoća trigonometrijskih točaka dosegla duljinu od $40 \mathrm{~km}$ po točki. Ministarstvo obrazovanja Albanije zatražilo je 1925. godine od 
which to create other maps in different scales. Regarding topographic maps in the scale 1:50,000 during the First World War, the main ones were published by the Italian and French military services, but according to assessments by experts, did not contain complete information. It was on the basis of these maps that the International Cartographic Commission signed Agreements on the state borders between Albania and Greece (27 January 1926) and between Albania and Yugoslavia (26 July 1926) in Florence, Italy. When the state of Albania was declared on 28 November 1912, a conference of ambassadors was held in London at which its current borders were established. An international cartographic commission was also established, consisting of representatives from Austria, Italy, Germany, England, France and Russia. It began its work in 1922 and ended it in 1925. On the basis of these maps and descriptions of material protocols, the Albanian-Greek border was confirmed in Florence on 27 January 1926, the Albanian-Yugoslav border on 26 July 1926, and the Albanian-Italian border (that is, the Adriatic Sea border) on 8 April 1927 (Shehu, Nikolli 2001).

\section{Cartography of Albania After the Second World War}

The period between 1945 and 2000 fell into four phases in terms of cartographic work in Albania. Each had specific features (Shehu, Nikolli 2001).

- Phase one: 1945-1955, production of a map of Albania in the scale 1:50,000

- Phase two: 1956-1970, production of a topographic map in the scale 1:25,000 covering the entire area of Albania

- Phase three: 1970-1992, production of a topographic map of Albania in the scale 1:10,000

- Phase four: 1992 to the present day, characterised by huge transformations in Albanian society and all its activities, including the area of cartography.

\subsection{Topographic maps of Albania}

The following institutes are primarily credited with the development of topographic maps: the Military Geographic Institute (Vienna, Austria), the Imperial Military Geographic Institute (Florence, Italy), the Military Cartographic Geodetic Institute (Germany), the Geodesic Cartographic Institute (Russia) and the Military Topographiy Institute of the Albanian Army (Shehu, Nikolli 2001).

- Topographic maps in the scale 1:10,000 were printed between 1977 and 1991 by the Imperial
Military Geographic Institute in Florence, Italy. In total, 379 maps were published.

- Topographic maps in the scale 1:25,000 were printed between 1959 and 1965 and between 1959 and 1985 by the Russian Military Cartographic Institute.

- Topographic maps in the scale 1:50,000 were printed in 1948, 1952 and between 1976 and 1992 by the Russian Military Cartographic Institute.

- Topographic maps in the scale 1:100,000 were printed in 1941 and between 1978 and 1988 by the French Military Geographic Institute.

- Topographic maps in the scale 1:200,000 were printed between 1983 and 1985 and in 1988 by the Topographic Military Institute of Albania.

- Topographic maps in the scale 1:500,000 were printed between 1951 and 1956 by the Topographic Military Institute of Albania.

\subsection{Maritime charts of Albania}

The number of maritime charts produced in $\mathrm{Al}-$ bania was insufficient. This was particularly true in relation to the demands of the education system, along with certain scientific institutions. This occurred because of several factors, of which the main one was the unenviable state of economic growth in Albania. After the Second World War, the leaders of the state paid more attention to the production of topographic maps and less to maritime charts. A second factor was the appearance and wide dissemination of thematic maps which did not focus on the right goals. Cartography attracted far less attention than it deserved, and in the end, this led to thematic maps lagging behind (Shehu, Nikolli 2001).

\section{Institutions Which Historically Dealt With Cartography}

\subsection{Military Geographic Institute}

The Military Geographic Institute in Albania is simultaneously a military and state institution, tasked with implementing scientific research and maintaining and monitoring the work of the state geodetic network. Existing topographic maps made a great contribution towards geological work in the sense of exploratory research in geophysics, widening the perspective in many other sciences too, particularly when studying environmental issues. In 1951, the Higher Polytechnic Institute was founded in Albania, and in 1991, under the former system, all faculties were regrouped to form the Polytechnic

KiG No. 34, Vol. 19, 2020, https://doi.org/10.32909/kg.19.34.1 - 
Bečkog vojnogeografskog instituta da ponovno objavi kartu Albanije u mjerilu 1:75 000, u Gauss-Krügerovoj projekciji. Karte u izdanju Bečkog vojnog geografskog instituta poslužile su Republici Albaniji kao kartografska osnova za stvaranje i drugih karata različitih mjerila. Što se tiče topografskih karata mjerila 1:50 000 tijekom Prvoga svjetskog rata, glavne su karte objavile talijanske i francuske vojne službe, no karte, prema procjenama stručnjaka, nisu imale potpune podatke. Na temelju tih karata Međunarodna kartografska komisija u Firenci u Italiji potpisala je Sporazum o državnoj granici između Albanije i Grčke (27. 1. 1926.), kao i onaj o državnoj granici između Albanije i Jugoslavije (26. 7. 1926.). Nakon proglašenja Albanije 28. studenoga 1912. godine održana je Londonska konferencija ambasadora na kojoj su utvrđene njezine današnje granice. Osnovana je i Međunarodna kartografska komisija s predstavnicima iz Austrije, Italije, Njemačke, Engleske, Francuske i Rusije. Ona je započela s kartografskim radovima 1922., a završila 1925. godine. Na temelju tih karata i opisa materijala protokola, potpisom je u Firenci 27. 1. 1926. utvrđena albansko-grčka granica, 26. 7. 1926. albanska granica s tadašnjom Jugoslavijom te 8. 4. 1927. albansko-talijanska granica, tj. granica na Jadranskome moru (Shehu, Nikolli 2001).

\section{Kartografija Albanije nakon Drugoga svjetskog rata}

Razdoblje od 1945. do 2000. godine, vezano za kartografske radove u Albaniji, podijeljeno je u četiri faze, od kojih se svaka razlikuje po određenim specifičnim obilježjima (Shehu, Nikolli 2001).

- Prva faza: 1945-1955. godine, izdana je karta Albanije mjerila 1:50 000.

- Druga faza: 1956-1970. godine, izdana je topografska karta mjerila 1:25 000 koja obuhvaća cijelo područje Albanije.

- Treća faza: 1970-1992. godine, izrađena je topografska karta Albanije u mjerilu 1:10 000.

- Četvrta faza: od 1992. godine nadalje. Karakteriziraju je velike transformacije u životu albanskoga društva, a time i svih njegovih aktivnosti, uključujući i područje kartografije.

\subsection{Topografske karte Albanije}

Za razvoj topografskih karata prvenstveno su zaslužni poznati instituti: Vojnogeografski institut, Austrija (Beč), Carski vojnogeografski institut, Italija (Firenca), njemački Vojni kartografski geodetski institut, ruski Geodetski kartografski institut te Vojni topografski institut albanske vojske (Shehu, Nikolli 2001).

- Topografske karte u mjerilu 1:10 000 tiskao je u razdoblju 1977-1991. Carski vojno-geografski institut iz Italije (Firenca). Ukupno je 379 objavljenih karata.

- Topografske karte u mjerilu 1:25 000 tiskao je u razdoblju 1959-1965. i 1959-1985. Vojno-kartografski institut Rusije.

- Topografske karte u mjerilu 1:50 000 tiskao je 1948., 1952. te u razdoblju 1976-1992. Vojno-kartografski institut Rusije.

- Topografske karte u mjerilu 1:100 000 tiskao je 1941. te 1978-1988. Vojno-geografski institut iz Firence.

- Topografske karte u mjerilu 1:200 000 tiskao je 1983-1985. te 1988. godine Topografski vojni institut Albanije.

- Topografske karte u mjerilu 1:500 000 tiskao je 1951-1956. Topografski vojni institut Albanije.

\subsection{Pomorske karte Albanije}

Količina proizvedenih pomorskih karata u Albaniji nije bila dostatna. Posebice se to odnosi na nemogućnost ispunjavanja zahtjeva škola, kao i mnogih drugih znanstvenih institucija. Do takvog je stanja došlo zbog više faktora, prvenstveno poradi postojećih nezavidnih uvjeta ekonomskog razvoja u Albaniji. Nakon Drugoga svjetskog rata tadašnji državni vrh pažnju je najviše usmjerio na topografske karte, a na štetu pomorskih. Drugi se faktor odnosi na tematske karte i njihovu široku i raznorodnu rasprostranjenost koja nije bila usmjerena k pravim ciljevima. Predmet kartografije svakako je budio puno manje zanimanja no što je to bilo potrebno, što je na koncu rezultiralo velikom zaostalošću tematskih karata (Shehu, Nikolli 2001).

\section{Institucije koje su se kroz povijest bavile kartografijom}

\subsection{Vojnogeografski institut}

Vojnogeografski institut u Albaniji jest istodobno i vojna i državna institucija koja je zadužena za provođenje znanstvenih istraživanja te za održavanje i kontrolu rada državne geodetske mreže. Već postojeće topografske karte dale su veliki doprinos geološkom radu u vidu izviđačkog istraživanja u geofizici šireći perspektivu gledanja i u mnogim drugim znanostima, a osobito pri proučavanju problematike okoliša. Godine 1951. osnovan je Visoki politehnički 
University of Tirana. In 2007, as a result of reforms undertaken by the Albanian government to encourage more successful, effective scientific research, the composition and structure of the Polytechnic University were changed. It now comprises six faculties and the Institute for Researching Polytechnic Development, along with the Department of Geodesy and Cartography. The Office of the Geography Centre was founded in 1971 as a scientific-research institution. In 1979 it ceased to be administered by the University of Tirana and was attached to the Hydrometereological Institute in Tirana. From 1993 to 1995, the Centre prepared 14 atlases for printing, in which the potential for coastal tourism was assessed, along with some mountainous areas. One of the greatest achievements was the creation of a map in the scale 1:100,000 covering the entire territory of Albania. This map was produced with the aid of satellite images (correction and transformation in the scale 1:100,000 and was completed in 1999 (Shehu 2013).

\subsection{Agency for Legalisation, Urbanisation and Integration of Informal Areas and Buildings (ALUIZNI)}

According to the data of the Ministry of Public Works, Transport and Telecommunications, the Agency for Legalisation, Urbanisation and Integration of Informal Areas and Buildings (Agjencia e Legalizimit, Urbanizimit dhe Integrimit the Zonave dhe Ndertimeve Informale - ALUIZNI) in the Republic of Albania is the central public institution and legal entity. In this context, ALUIZNI was founded as an executive structure responsible for managing complex reforms in three main areas: legalisation, urbanisation, and integration of informal areas/settlements in the whole country (Wikipedia 2012a).

\subsection{GIS-Albania}

GIS-Albania was founded in 1992 with the aim of developing digital geoinformation systems in $\mathrm{Al}$ bania. The purposes of the company, apart from providing traditional cartographic services, is to provide clients with new services which were not previously available in the country - map digitalisation, GIS and LIS. GIS-Albania provides other, classic topo-geodetic services, such as surveying in various degrees and working on updating topographic maps, building up geodetic networks, topographic work in engineering objects, and so on. The quality of services

10 provided by GIS-Albania is the result of many experiences over the past 20 years. GIS-Albania has a staff who are prominent experts in various fields of human activity, such as engineering design, urban studies, environmental protection, geological studies, and so on (Google 2012b).

\subsection{State Administration for Geospatial Information (ASIG)}

The State Administration for Geospatial Information (Autoriteti Shtetëror për Informacionin Gjeohapësinor - ASIG) was founded in 2012. It is authorised to build the geodetic referential framework of the Republic of Albania in line with European standards, so that through the use of modern tools and methods, accurate geodetic and cartographic tasks can be performed for the development, work and updating of GIS and the National Geoportal, which provides information, data and geospatial services in full alignment with the standards of EC Directive 2007/2 INSPIRE. ASIG coordinates and cooperates with public bodies to collect, process and update geospatial information and to create and implement standards in the area of geoinformation. The National Geoportal allows professional users and the public, through internet services, and in a simple, quick way, to search, read and access geospatial information which has been made available to public bodies responsible for collection, processing and updating. Its creation directly serves an open government which basically promotes an open-data policy for citizens, providing high quality services. The final version of the National Geoportal (completed in 2017) is the greatest step ASIG has taken in creating a national infrastructure of geospatial information in Albania. Special thanks are due to the Norwegian government, which financed the National Geoportal through the Norwegian Mapping and Cadastre Authority (Statens Kartverk), and which continues to help ASIG to fulfil its mission (Google 2020a).

\section{The State of Cartography in Albania}

The developmental level of cartography has always depended on the current economic situation in the country. Achievements in the area of cartographic education are stored in the 'cartographic library archive'. Recently, Albania has not made any significant, specific steps or taken any particular measures in the area of cartography. No cartographic society has been formed to deal exclusively with this

KiG No. 34, Vol. 19, 2020, https://doi.org/10.32909/kg.19.34.1 - 
institut u Albaniji, a 1991., tijekom prethodnog sustava, svi su se fakulteti pregrupirali te se oformilo Politehničko sveučilište u Tirani. Godine 2007., kao rezultat reformi koje je poduzela albanska Vlada u korist poticanja sve uspješnijeg i učinkovitijeg znanstvenog istraživanja u Albaniji, mijenja se sastav i struktura Politehničkog sveučilišta u Tirani. Ono se trenutačno sastoji od šest fakulteta i Instituta za istraživanje politehničkog razvoja, a tu je i Odsjek za geodeziju i kartografiju. Ured Geografskog centra utemeljen je 1971. godine kao znanstvenoistraživačka institucija. Ona se 1979. godine odvaja od administracije Sveučilišta u Tirani te se združuje s Hidrometeorološkim institutom u Tirani. U razdoblju od 1993. do 1995. godine Centar je pripremio za tisak 14 atlasa u kojima se procjenjuje potencijal obalnog turizma, ali i nekih planinskih područja. Jedno od najuspješnijih postignuća jest stvaranje karte u mjerilu 1:100 000 koja pokriva čitav albanski teritorij. Stvaranje te karte s pomoću satelitskih snimaka (korigiranje i transformiranje u mjerilo 1:100 000) dovršeno je 1999. godine (Shehu 2013).

\subsection{Agencija za legalizaciju, urbanizaciju i integraciju neformalnih područja (ALUIZNI)}

Prema podatcima Ministarstva za javne radove, promet i telekomunikacije Agencija za legalizaciju, urbanizaciju i integraciju neformalnih područja/ građevine $\mathrm{u}$ Republici Albaniji (Agjencia e Legalizimit, Urbanizimit dhe Integrimit the Zonave dhe Ndertimeve Informale - ALUIZNI) jest središnja javna ustanova i pravna osoba. U tom je kontekstu ALUIZNI osnovan kao izvršna struktura odgovorna za upravljanje i složene reforme koje će se provoditi kroz tri glavne točke: legalizaciju, urbanizaciju i integraciju područja/neformalnih naselja u cijeloj zemlji (Wikipedia 2012a).

\subsection{GIS-Albanija}

Tvrtka GIS-Albanija osnovana je 1992. godine s ciljem razvoja digitalnih geoinformacijskih sustava u Albaniji. Svrha tvrtke, osim tradicionalnih kartografskih usluga, jest pružiti korisnicima nove usluge koje prije toga nisu bile dostupne u zemlji - digitalizaciju karata, GIS i ZIS. GIS-Albanija nudi i druge, klasične topo-geodetske usluge kao što su istraživanje različitih mjerila i rad na osuvremenjivanju topografskih karata, rad na izgradnji geodetskih mreža, topografski radovi u inženjerskim predmetima itd. Kvaliteta usluga koje pruža GIS-Albanija jest rezultat brojnih dosadašnjih iskustava tijekom posljednjih 20 godina. GIS-Albanija ima svoje suradnike koji su najistaknutiji stručnjaci u različitim područjima ljudskih djelatnosti, kao što su: inženjering dizajna, urbane studije, zaštita okoliša, geološke studije itd. (Google 2012b).

\subsection{Državna uprava za geoprostorne informacije (ASIG)}

Državno tijelo za geoprostorne informacije (Autoriteti Shtetëror për Informacionin Gjeohapësinor ASIG) osnovano je 2012. godine. Ovlašteno je graditi geodetski referentni okvir Republike Albanije u skladu s europskim standardima kako bi se suvremenim alatima i metodama omogućilo izvođenje točnih geodetskih i kartografskih radova, razvoj, rad i ažuriranje GIS-a i Nacionalnoga geoportala koji pruža informacije, podatke i geoprostorne usluge $u$ potpunosti u skladu sa standardima Direktive 2007/2 / EZ INSPIRE. ASIG koordinira i surađuje s odgovornim javnim tijelima za prikupljanje, obradu i ažuriranje geoprostornih informacija te izradu i primjenu standarda u području geoinformacija. Nacionalni geoportal omogućava profesionalnim korisnicima, ali i javnosti, putem mrežnih usluga, da na jednostavan $\mathrm{i}$ brz način pretražuju, pregledavaju i pristupaju geoprostornim informacijama koje su stavljene na raspolaganje javnim tijelima odgovornima za prikupljanje, obradu i ažuriranje. Njegova izrada izravno služi otvorenoj vladi koja u osnovi ima politiku otvorenih podataka za građane pružajući kvalitetne usluge. Nacionalni geoportal u svojoj konačnoj verziji (realiziran u rujnu 2017.) najvažniji je korak ASIG-a u stvaranju Nacionalne infrastrukture geoprostornih informacija u Albaniji. Posebna zahvala za pomoć ide norveškoj vladi koja je preko norveške Uprave za kartografiju i katastar, Statens Kartverk, financirala razvoj Nacionalnoga geoportala te i dalje pomaže ASIG-u u ispunjavanju njegove misije (Google 2020a).

\section{Stanje kartografije u Albaniji}

Razina razvoja kartografije oduvijek je bila uglavnom uvjetovana tekućom ekonomskom situacijom u zemlji. Dostignuća u području kartografskog obrazovanja pohranjena su u postojeću „kartografsku književnost/arhiv“. Albanija nije ostvarila važne i konkretne korake, odnosno mjere u području kartografije. Nije osnovana niti jedna kartografska udruga koja bi se pozabavila isključivo i primjereno ozbiljno tom tematikom. Sudjelovanje Albanije u radu međunarodnih organizacija nije zadovoljavajuće. Do 1992. godine je, zbog sada već poznatih političkih 
topic. Albania does not participate sufficiently in the work of international organisations. Up to 1992, due to political reasons which are well-known, it was extremely difficult, in fact virtually impossible, to establish international relations with the desired and necessary relevant organisations dealing with cartography. However, in the last 28 years, as the country has undergone an extremely difficult and painful political and economic transition, it has not been easy to establish cooperation with the relevant cartographic organisations either. A huge problem in terms of the further development of cartography in Albania is the fact that, in spite of the overall known situation, no initial steps towards implementing further development and promotion have been taken. International standards are rising day by day, and it is impossible to imagine the modern world functioning in any area of human activity without technology. Technology is developing at lightning speed, so any country needs to keep up to a certain extent, if it expects in the future to achieve any progress and realise its full potential (Shehu 2013).

\section{Conclusion}

The research focused on maps by well-known Venetian cartographers which show Albania with toponyms in Albanian. An important event took place in 2017 when the famous Albanian cartographer Artn Shkreli was allowed by the terms of an interstate agreement to bring the copy of a nautical chart from the National Library in Rome to the National Museum in Tirana, where it is now housed and is accessible to the wider public. Under the supervision of the then Albanian Ministry of Education, various maps were published by the Viennese Military Geographic Institute and Italian and French military cartographic services, which later served the International Cartographic Commission, comprising representatives from Austria, Italy, Germany, England,
France and Russia as a basis for establishing the present-day state borders of the Republic of Albania. After the Second World War, cartography in Albania fell more or less into four phases, when various maps were produced thanks to prominent cartographic institutions such as the Military Geographic Institute (Vienna, Austria), the Imperial Military Geographic Institute (Florence, Italy), the Military Cartographic Geodetic Institute (Germany) and the Geodesic Cartographic Institute (Russia), with the close professional coopertion of the Military Topographiy Institute of the Albanian Army. In addition, major contributions were made by local scientific-research institutions - the Military Topography Institute of the Albanian Army, the Military Geographic Institute of Albania, the Higher Polytechnic Institute of Albania, the Polytechnic University of Tirana (Department of Geodesy and Cartography, and the Office of the Geography Centre), the Hydrometereological Institute in Tirana, the Agency for Legalisation, Urbanisation and Integration of Inofrmal Areas and Building (ALUIZNI), GIS-Albania and the State Administration for Geospatial Information (ASIG). Due to the historical challenges which Albania has faced, particularly in the last 28 years, and the extremely difficult and painful political and economic transition through which it has gone, the country has not been able to participate sufficiently in the work and activities of international cartography and geoinformation organisations.

The level of development in the areas of cartography and geoinformation have also been inadequate. The State Administration for Geospatial Information (ASIG) has made an important initial step in the direction of development. Development, work and updating data in the areas of cartography and geoinformation and the National Geoportal, which provides information, data and geospatial services, are fully aligned with the standards of EC Directive 2007/2 INSPIRE. 
razloga, bilo izuzetno teško, gotovo neizvedivo uspostaviti međunarodne odnose sa željenim i potrebnim relevantnim organizacijama koje se bave kartografijom. No u posljednjih 28 godina, prolaskom kroz vrlo tešku i mukotrpnu političku i ekonomsku tranziciju, nije bilo jednostavno uspostaviti suradnju s relevantnim kartografskim organizacijama. Veliki je problem za daljnji razvoj kartografije Albanije činjenica da se po tom pitanju, unatoč cjelokupnoj poznatoj situaciji, ipak nisu učinili barem inicijalni koraci u svrhu daljnjeg nužnog razvoja i promidžbe. Svjetski su standardi, naime, svakim danom sve viši, a tehnologija je nešto bez čega je funkcioniranje suvremenoga svijeta u bilo kojem području ljudskoga djelovanja nezamislivo. Ona napreduje munjevitom brzinom te bi svaka zemlja morala, barem do neke određene mjere, ići ukorak s njom ako želi u budućnosti osigurati ikakav napredak i iskazati vlastiti puni potencijal (Shehu 2013).

\section{Zaključak}

Istraživanje je uglavnom rađeno na kartama poznatih kartografa iz Venecije, gdje je Albanija prikazana s toponimima na albanskom jeziku. Značajan je događaj onaj iz 2017. godine kada je poznati albanski kartograf Artan Shkreli međudržavnim sporazumom donio kopiju nautičke karte iz Nacionalne knjižnice u Rimu, koja se od tada čuva u albanskom Nacionalnom muzeju u Tirani i dostupna je široj javnosti. Pod nadzorom tadašnjeg Ministarstva obrazovanja Albanije objavljivane su razne karte Bečkog vojnogeografskog instituta i talijanske i francuske kartografske vojne službe koje su kasnije međunarodnom kartografskom povjerenstvu sastavljenom od predstavnika Austrije,
Italije, Njemačke, Engleske, Francuske i Rusije poslužile kao osnova za utvrđivanje državne granice koju danas ima Republika Albanija. Kartografija Albanije nakon Drugoga svjetskog rata može se podijeliti u četiri faze kada su objavljene različite karte zahvaljujući prvenstveno tadašnjim najuglednijim međunarodnim kartografskim institucijama kao što su Vojnogeografski institut iz Beča (Austrija), Carski vojno-geografski institut iz Firence (Italija), Vojni kartografski geodetski institut iz Njemačke, Geodetski kartografski institut iz Rusije, uz blisku profesionalnu suradnju Vojnog topografskog instituta albanske vojske. Također, veliki su doprinos dale lokalne znanstveno-istraživačke institucije - Vojni topografski institut albanske vojske, Vojno geografski institut Albanije, Visoki politehnički institut u Albaniji, Politehničko sveučilište u Tirani (Odsjek za geodeziju i kartografiju) te Ured Geografskog centra, Hidrometeorološki institut u Tirani, Agencija za legalizaciju, urbanizaciju i integraciju neformalnih područja (ALUIZNI), GIS-Albanija i Državna uprava za geoprostorne informacije (ASIG). Zbog povijesnih izazova kroz koje je Albanija prošla, posebno posljednjih 28 godina, vrlo teške i naporne političke i ekonomske tranzicije, sudjelovanje Albanije u radu i aktivnostima kartografije i geoinformacija $u$ međunarodnim organizacijama nije zadovoljavajuće.

Razina razvoja područja kartografije i geoinformacija također nije bila zadovoljavajuća. Državna uprava za geoprostorne informacije (ASIG) ostvarila je vrlo važan početni korak u smjeru razvoja. Razvoj, rad i ažuriranje podataka iz područje kartografije i geoinformacija i Nacionalnog geoportala koji pruža informacije, podatke i geoprostorne usluge, u potpunosti su u skladu sa standardima Direktive 2007/2 / EZ INSPIRE.

\title{
References / Literatura
}

\author{
Google (2012a) Albanian Historical Forum, http://www.forum-al.com, pristup 5. lipnja 2012. \\ Google (2012b) GIS Albania, https://www.geospatialworld.net/companies/51094/gis-albania/, pristup 22. lipnja 2012. \\ Google (2020a) State Authority for Geospatial Information, http://www.asig.gov.al, pristup 5. svibnja 2020. \\ Google (2020b) The National History Museum of Albanija, http://www.mhk.gov.al, pristup 12. travnja 2020. \\ Shehu A, Nikolli P (2001) Historia e Hartografisë Shqiptare, Juvlin, Tirana \\ Shehu F (2013) Kartografija Jadrana Albanije, seminarski rad, Geodetski fakultet, Zagreb \\ Shkreli A (2017) Imago Albaniae - fytyra hartografike e vendit ne shekuj, Tirana \\ Wikipedia (2012a) Legalization Agency of Urbanization and Integration of Informal, \\ https://en.wikipedia.org/wiki/ALUIZNI_(Albania), pristup 22. lipnja 2012. \\ Wikipedia (2012b) The free encyclopedia, Butrint City, https://sq.wikipedia.org/wiki/Butrinti, pristup 28. travnja 2012
}

